\title{
АНАТОЛИЙ В. КУЛАГИН, «Я В ЭТОМ ГОРОДЕ ПРОВЁЛ ВСЮ ЖИЗНЬ СВОЮ...»: ПОЭТИЧЕСКИЙ ПЕТЕРБУРГ АЛЕКСАНДРА КУШНЕРА, КОЛОМНА: МОСК. ГОС. ОБЛ. СОЦ.-ГУМАНИТ. ИН-Т. 2014, 140 С.
}

Александр Семенович Кушнер - один из самых ярких представителей российской классической поэзии второй половины XX - начала XXI вв. Творчество автора около пятидесяти стихотворных сборников, многочисленных статей и эссе о русской поэзии постоянно привлекает внимание как критиков, так и литературоведов. Свидетельствуют об этом отклики на каждую новую книгу стихов поэта, научные статьи, а также диссертационные и монографические исследования. На этом фоне вышедшая в 2014 году книга доктора филологических наук Анатолия В. Кулагина «Я в этом городе провёл всю жизнь свою...»: Поэтический Петербург Александра Кушнера представляет несомненный интерес и заслуживает особого внимания. Она заполняет пробел в научной литературе, поскольку существенно уточняет и дополняет источниковедческую базу кушнероведения. Отметим, что до сих пор вышла из печати лишь одна монография, посвященная лирике Кушнера, и то в 1992 г. (ср. Д. Б. Пэн, Мир в поэзии А. Кушнера, Ростов-на-Дону: изд-во Ростовского ун-та).

Рецензируемая книга посвящена рассмотрению образа Петербурга, запечатленного в стихотворениях Кушнера разных лет. Это солидное литературоведческое исследование, в котором на первый план выдвигается мотивно-образный анализ. Поэтические тексты Кушнера рассматриваются исследователем с привлечением широкого историко-культурного, литературного, биографического, географического, бытового контекстов. Материалом для анализа послужило самое полное издание стихотворений Кушнера - Избранное (Москва: Время, 2005), отдельные сборники его стихов, а также их журнальные публикации. В итоге Кулагин анализирует довольно солидный корпус стихотворений (по нашему подсчету 134 текста), прослеживая эволюцию кушнеровского образа Петербурга. Конечно, круг текстов, на которых основано исследование, намеренно ограничен. Сам автор отбор материала мотивирует следующим образом:

Не все, что написано Кушнером о Петербурге, рассматривается на ее [книги - Э. С.] страницах. Во-первых, нам хотелось выделить лишь ведущие, на наш взгляд, грани темы, и ради цельности этой работы нам пришлось оставить за ее бортом многие замечательные произведения поэта о своем городе. А во-вторых - «петербургский текст» нашего героя поистине необъятен из-за того, что даже если в стихах не упомянуты ни 
сам город, ни конкретные его реалии, все же читатель, благодаря общей атмосфере творчества поэта, неизбежно ощущает их как петербургские [...] (c. 3-4).

Отбор конкретных художественных произведений достаточно отчетливый (хотя смущает немного факт, что корпус составляют в основном ранние стихотворения поэта; лишь изредка рассматриваются в книге более поздние по времени написания тексты). Кулагиным выбраны лишь те тексты Кушнера, в которых наглядно прослеживается как эволюция поэтического воплощения города на Неве, так и специфика его видения, т. е. индивидуальное авторское восприятие Петербурга.

Эта задача определяет и структуру монографии, состоящей из пяти глав, сфокусированных на важнейших, по мнению Кулагина, аспектах поэтического образа города: это лирическое переживание его истории, отголоски «петербургского мифа», мотивы дома, сада, впечатления от музеев и прогулок. В работе названия глав отсутствуют. Вместо них - цитаты из стихотворений поэта. Это, конечно, корреспондирует как с заглавием монографии, так и с общей концепцией книги. Исследование завершается традиционно списком рассматриваемых либо цитированных стихотворений Кушнера и именным указателем.

Проследим за концепцией книги Кулагина.

В первой главе - «Как бы увиденный сквозь сон...» - исследователем рассматриваются стихотворения Кушнера, основу которых составляет «петербургский миф». Поэт обыгрывает ядерные составляющие городской мифологии: выбор Петром Великим места для строительства города, мотив Венеции как прообраза Петербурга, сочетание действительного и воображаемого, мотивы сна и гибели, а также илюзорности и призрачности города. Именно с мотивов ирреальности, как полагает Кулагин, началась у Кушнера разработка петербургской темы. В центре внимания исследователя оказались стихотворения разных лет, часто не включенные поэтом в книги избранного, в них-то, по мнению литературоведа, заключен интересный поворот петербургской темы.

Обращаясь к «петербургскому мифу», поэт вступает в диалог с русской классической литературой. Однако, как справедливо отмечает автор монографии, Кушнер разрабатывает связанные с ним темы и сюжеты совсем по-другому, чем его предшественники. С одной стороны, следуя сложившейся литературной традиции, современный поэт развивает ее основные идеи, с другой - преодолевает традицию, противопоставляя ей свой взгляд, свой особый ракурс. Так, признавая вслед за поэтами-предшественниками призрачность города (чему способствуют его метеорологические особенности), Кушнер полемизирует с его губительной метафизикой. Видит что-то прекрасное, близкое сердцу в этом фатализме. На протяжении почти шестидесяти лет поэт доказывает, что можно жить и любить в этом городе. 
Очередная глава («Счастье прогулки свободной») посвящена сквозному мотиву лирики Кушнера. Лирическая ситуация прогулки разработана во многих его стихотворениях; поэт моделирует ее либо в центре города, либо на окраинах. Это не просто развлечение, а повод для лирического переживания. По мнению Кулагина, «прогулка важна для него [Кушнера Э. С.] не как простое развлечение, а как источник раздумий [...], эмоциональных и эстетических впечатлений» (с. 30). Поэт рефлексирует не только на тему своей судьбы, но и истории и культуры России. Потому что у Кушнера прогулка почти всегда овеяна историко-культурными или литературными ассоциациями, различными, иногда трудно улавливаемыми, подтекстами.

В этой связи представляют интерес наблюдения Кулагина, касающиеся стихотворения семидесятых годов, которое стало хрестоматийным «Пойдем же вдоль Мойки, вдоль Мойки...». Не анализируя весь мотивно-образный пласт стихотворения, литературовед обнаруживает и комментирует тонкие биографические, историко-культурные, мифологические, общественные подтексты, в нем заложенные, которые до сих пор не были объектом отдельного исследования (с. 40-45).

Внимания заслуживает тщательный анализ еще одного, и к тому же мало известного, стихотворения 1961 года «Ветра невского свирепость...», опубликованного в первом сборнике Кушнера (Первое впечатление, 1962) и не попавшего в дальнейшем ни в один сборник избранных стихов поэта (кроме сборника, адресованного детям Город в подарок, 1976). Кулагин считает его очень важным, так как в нем представлен «любопытный, - по мнению литературоведа, - по-петербургски точный, поэтический взгляд» (c. 31). На этот раз касается он Петропавловской крепости. Внимание исследователя приковано к смене ракурса, благодаря которой известнейшая петербургская постройка воспринимается лирическим героем стихотворения по-разному. С большей подробностью Кулагин описывает особенности планировки Петроградской стороны (района, в котором вырос поэт), поясняя тем самым смысл стихов: «В каждом тихом переулке - / Петропавловка своя!» (с. 32). Заложенные в этом стихотворении скрытые подтексты помогает обнаружить и анализ его метрической стороны. Оно написано четырехстопным хореем, который, с одной стороны, ассоциируется с «дорожными» стихотворениями А. С. Пушкина (Зимняя дорога, Бесы и др.), с другой - с детской литературой XX в. (отметим, что Кушнер пишет также стихи для детей).

Анализ «прогулочных» стихотворений привел Кулагина к проницательным наблюдениям о том, что с временем гуляющий по Петербургу лирический герой Кушнера воспринимает город (и мир вообще) все более гармонично (с. 56). Таким образом, в творчестве петербургского поэта обнаруживается современный период в восприятии и изображении города на Неве, отмеченный ситуацией соединения города и героя, 
взаимопрорастания их. Вспомним, что на эту особенность поэтического восприятия Петербурга Кушнером указывала в свое время Лариса Е. Ляпина ${ }^{1}$.

В третьей главе («Да, имперский. А Вы бы хотели...») образ Петербурга анализируется в связи с топосом России. Тема рассматривается в контексте классической и более современной Кушнеру поэзии. Кулагин исследует переклички поэта - литературные заимствования, интертекстуальный диалог - с русской классикой и поэтами Серебряного века. Вслед за В. Жуковским, А. Пушкиным, О. Мандельштамом, И. Анненским и др. Кушнер включается в лирическую тему «большой страны» - ее истории и судьбы, используя мотивы холода, метели, петровскую тему и др. Наблюдая за развитием петровской темы у Кушнера, литературовед обращает внимание на сугубо личное, интимное восприятие Петра Первого, что в общем уникально в русской поэзии (с. 71).

Как известно, Петербург возник и долгое время существовал как город имперский. Свидетельствуют об этом многочислительные достопримечательности, а также вся его история и культура - литература, искусство, архитектура. Таким - имперским по своей сути - и воспринимает его современный поэт (с. 76).

Глава «Условность как данность» посвящена поэтическому видению Петербурга Кушнером как города культуры и исскуства. Рассматриваются в ней стихотворения, пропитанные историко-культурной атмосферой города, в том числе т. н. «эрмитажные» стихотворения, стихотворения о голландской живописи и ее мастерах, архитектурные стихотворения, в которых творчески переживаются Кушнером различные стили: барокко, ампир, модерн. Кулагин обоснованно, на конкретных примерах доказывает, что искусство Петербурга - в различных его проявлениях - является естественной почвой и основой творчества и мировосприятия Кушнера (с. 107).

Монографию завершает глава «Где наш дом? - За Таврическим садом...». Она посвящена рассмотрению генезиса и эволюции образа Таврического сада в лирике Кушнера. По точному замечанию Кулагина, это особый локус на карте Петербурга, занимающий важное место как в творческом сознании поэта, так и в его личной жизни (с 1980-х гг. Кушнер живет в районе, который примыкает к Таврическому саду). Таврический сад как своеобразный Genius loci вызывает у Кушнера многочисленные историко-культурные ассоциации: с античностью (столь важной для поэта), русской классикой (с К. Батюшковым, А. Пушкиным, Ф. Достоевским и др.), поэтами Серебряного века (петербуржцами А. Блоком, И. Анненским, А. Ахматовой и др., столько раз проходившими через Таврический сад на башню к В. Иванову).

1 Л. Е. Ляпина, «Таврический сад» А. С. Кушнера: контекстуальное прочтение, [в:] Мир Петербурга в русской поэзии. Очерки исторической поэтики, Санкт-Петербург: Издательство «Нестор-История» 2010, с. 137. 
В нем сходятся важнейшие мотивы лирики Кушнера: снега, моря, творчества, дома, «большой страны».

Проведенный Кулагиным комплексный анализ в рамках целостного монографического исследования восполняет, как уже отмечалось, пробел в научной литературе и открывает новые грани творчества современного петербургского поэта. Автор книги предложил стройную, логическую концепцию понимания творчества Кушнера. Проблематика отдельных глав работы продиктована именно этой задачей: в ней нашли отражение климатические, урбанистические, исторические, литературные и мифопоэтические концепты, формирующие поэтический Петербург Кушнера.

Несомненным достоинством работы следует признать точность и подробный комментарий к рассматриваемым стихотворениям. Кулагин с увлечением описывает авторские пристрастия и доминанты, лейтобразы и интертекстуальные диалоги, возникающие в художественном пространстве текстов Кушнера. Уникальность монографии в том, что она авторизована. Кулагин давно лично знаком с поэтом. По ходу работы исследователь часто обращался к Кушнеру, о чем сам пишет во вступлении. Фрагменты переписки приводятся им иногда в примечаниях для подтверждения/одобрения своих интерпретаций.

Подытоживая, следует признать, что монография Кулагина будет интересна и полезна не только специалистам, но и тем, кто хочет глубже понять поэтический мир лирики Кушнера.

\section{Ewa Sadzińska}

Uniwersytet Łódzki Wydział Filologiczny Instytut Rusycystyki Zakład Literatury i Kultury Rosyjskiej ul. Pomorska 171/173 90-236 Łódź evasz@interia.pl 